BENT, A.C. 1963. Life histories of North American flycatchers, larks, swallows and their allies. Dover reprint. New York, N.Y. $555 \mathrm{pp}$

${ }^{5}$ FOY, D.j. 1985. Territorial combat. Bird Wat-
6 FOREST SERVICE, U.S. DEPT. OF AGRICULTURE. 1977. Cavity-nesting birds of North American forests. Agriculture Handbook No. 511. 112 pp.

\title{
UNUSUAL NESTING SITE FOR THE GREAT HORNED OWL
}

RAYMOND A. BELANGER, 412 McGillivray Drive, Weyburn, Saskatchewan. S4H $1 \mathrm{M} 1$ and NICK POSTEY, 536 Bannerman Street, Weyburn, Saskatchewan. S4H 1S9

Though the "hoot" of the Great Horned Owl alerted us of its nocturnal presence, we were not aware of its nesting intention. Most of us believed that these great owls migrated to southerly locations during the winter but returned to nest in our parkland areas to the north. This proved not to be the case in the spring of 1985.

Nick Postey had encountered the Great Horned Owls on the Souris Valley Regional Care Centre grounds in Weyburn as early as 1981. During one experience he discovered a pair of Great Horned Owls occupying a squirrel's nest high on a cottonwood tree. Yet Nick never noted the presence of any young and although he observed them several times in the vicinity, the owls seemed to disappear in February.

In January 1985 a pair of Great Horned Owls was discovered in a stand of evergreen trees on the Souris Valley Regional Care Centre grounds. Their coloration differed as one was pale, the other dark brown. A few days later, the pale owl was located across the Souris River by Ray Belanger and Nick Postey.
This area is characterised by flat grasslands with bush growth dispersed amongst scattered, tall old cottonwood and ash trees. The area, which was isolated from contact with people, had an unusual number of magpie nests.

During an early March evening walk through this magpie nesting area we noticed that a Great Horned Owl had occupied a nest some 20 feet up in an old ash tree. The nest was domed with a side entrance and the owl was distinctly visible through the abundance of dried sticks and twigs. This owl was dark brown. During several further visits this owl was still present in the nest, and often the pale owl was perched in a nearby tree. Later in March a newly- hatched Great Horned Owl chick was observed peering from the nest.

Of special interest to us was the choice of the nest. Great Horned Owls usually use the nests of Red-tailed Hawks, Bald Eagles, Herons or occasionally an old leafy nest of a squirrel.' In Saskatchewan, Swainson's and Red-tailed hawk nests are most commonly used. (Pers. comm. C.S. Houston, via D. Hjertaas). We were of 
the opinion that platform nests were preferred over the domed variety as a Great Horned Owl is too large to enter a magpie nest. However the front and part of the roof of this nest had fallen out, leaving ample space for the owl to enter (see photographs).

On 20 April Dale Hjertaas banded the fledgling owl. C.S. Houston (pers. comm. to D. Hjertaas) reports that of 1800 successful Great Horned Owl nestings, only one other was in a magpie nest.

1 TERRES, J.K. 1980. The Audubon Society encyclopedia of North American birds. Alfred A. Knopf, New York. 668 pp.

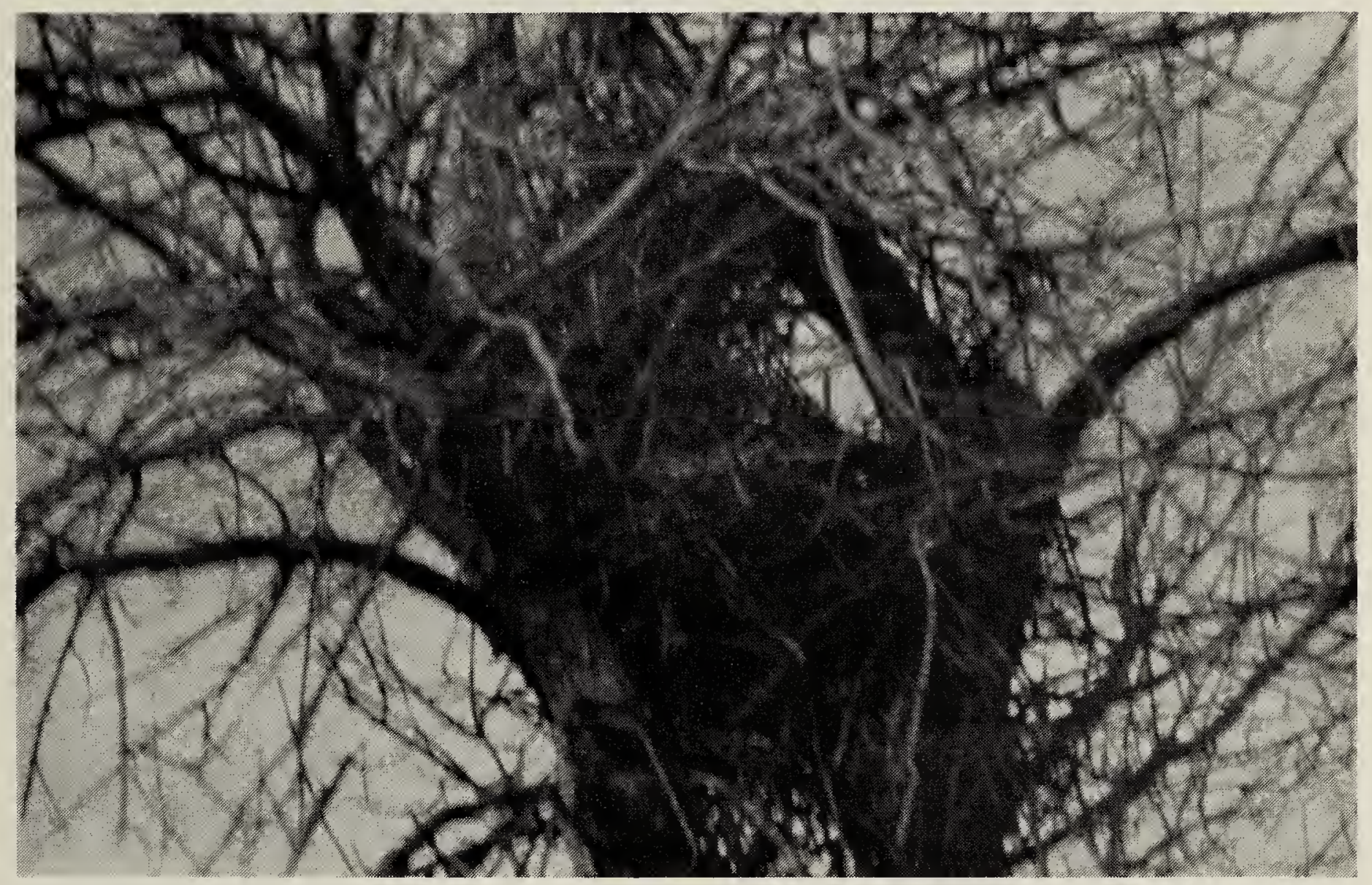

Magpie nest used by Great Horned Owls

Mabel Charlton

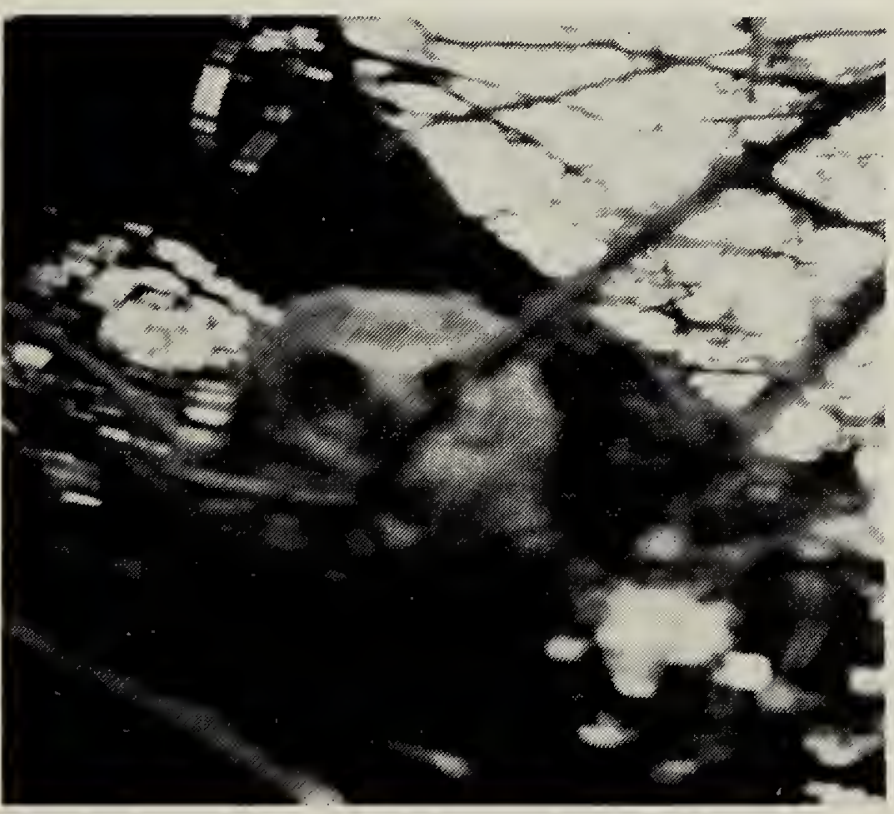

Young owl

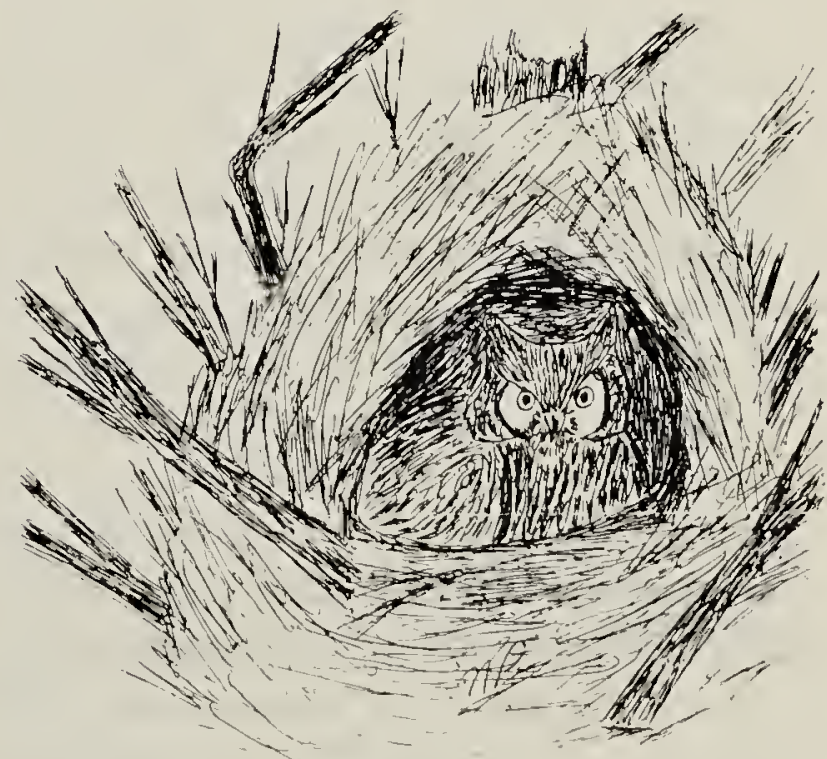

Nick Postey 